\title{
J. G. BALLARD’S INNER SPACE: THE JUXTAPOSITION OF TIME, SPACE AND BODY
}

\author{
Pedro Groppo
}

Doutorando em Estudos Literários

\begin{abstract}
The fiction of J. G. Ballard is unusually concerned with spaces, both internal and external. Influenced by Surrealism and Freudian psychoanalysis, Ballard's texts explore the thin divide between mind and body. This analysis of the story "The terminal beach" illustrates well some of the concepts present throughout his fiction.
\end{abstract}

KEYWORDS

Body, space, the uncanny

The fiction of J. G. Ballard is concerned with psychology, both by way of characters and their relationships, and an exploration of the real, outer world in terms of the mind. In reading Ballard, one should be attentive of spaces, how they inform and are informed by the characters’ psyches - be these spaces imagined or real. In 1962, writing for New Worlds, the avant-garde science fiction (SF) magazine of the sixties, Ballard advocated a separation between "inner” and “outer" spaces. He believed that, taking his cues from Sigmund Freud and the surrealists, "outer space” was no longer that important, and that writers should turn their attention to "inner space," meaning mind exploration rather than the space travel often depicted in the more generic flavor of SF. It was a true manifesto, and many took heed, turning Ballard into the champion of the "New Wave” of British SF. For him, "outer space” could only have any kind of interest if it were to mirror "inner space": "The biggest developments of the intermediate future will take place, not on the Moon or Mars, but on Earth, and its inner space, not outer, that needs to be explored. The only truly alien planet is Earth.” ${ }^{1}$ Ballard argued that SF was "the only medium with an adequate vocabulary” for the ideas and situations of the twentieth century, but that it still was sorely lacking in one aspect,

\footnotetext{
${ }^{1}$ BALLARD. A user's guide to the millennium, p. 197.
} 
and that was an emphasis on the psychological and the biological. For him, the human body and mind were the true technological apparatuses that SF should deal with, far more interesting than spaceships, robots or laser guns. His turn, then, to a speculative and imaginative fiction more informed of the workings of the mind, memory, fantasy, the body and its impulses, is completely justified by this need to explore the new thematic ground of the twentieth century.

To confirm his lineage to the surrealists, Ballard concludes the text with an allusion to Salvador Dali's delivering a lecture in London dressed in a diving suit. When asked how deep Dali proposed to descend, he answered, “To the unconscious”! Ballard feels that we need that inner space suit, and it is up to SF to build it. The period between 1962 and 1970, the year Ballard published The atrocity exhibition, his collection of avant-garde "condensed novels”, is his most prolific, with dozens of SF short stories and four novels (later he kept producing them, but in a much reduced number). In another essay for New Worlds, "The paranoid as artist”, Ballard conflated SF and surrealism, reading them as means of departing from accepted norms and received accounts of reality, ${ }^{2}$ which would produce a kind of "cognitive estrangement”, which, according to SF critics such as Darko Suvin, is an indispensable feature of SF. With The atrocity exhibition, he devised a new language and abandoned most of the more superficial devices of the genre - the four novels, for instance, all dealt with dystopian, post-catastrophe scenarios in a near future - but still maintaining its characteristic aura of estrangement.

The subject matter of SF is the subject matter of everyday life: the gleam on refrigerator cabinets, the contours of a wife's or a husband's thighs passing the newsreel images on a color TV set, the conjunction of musculature and chromium artifact within an automobile interior, the unique postures of passengers on an airport escalator. ${ }^{3}$

It is all about adopting a SF perspective to the real world and defamiliarizing it, uncovering hidden relations and logics to objects and situations of everyday life. According to Andrzej Gasiorek, SF offered Ballard a "way of exploring and perhaps coming to terms with the unprecedented scale of twentieth-century social and technological change, a way of grasping how and why human life had developed in the ways that it had", ${ }^{4}$ whereas surrealism "provided a technique for generating insights into the hidden logics that motivated

\footnotetext{
2 BALLARD. A user's guide to the millennium, p. 97.

3 BALLARD. Re/search 8/9, p. 99.

${ }^{4}$ GASIOREK. J. G. Ballard, p. 9.
} 
these developments; yet in another version of estrangement, it laid bare the unconscious processes that informed key aspects of external public life”. ${ }^{5}$ Ballard's fiction draws from both genres, as well as from Pop Art and the Gothic.

One of the key short stories in the Ballard canon, one that exemplifies his synthesis between techniques of Surrealism and SF, is “The terminal beach” (1964). In his introduction to The best SF of J. G. Ballard, he wrote that it is "the most important story I have written. It marks the link between the science fiction of my first ten years, and the next phase of my writings that led to The atrocity exhibition and Crash". ${ }^{6}$ In the same 1962 manifesto for New Worlds, Ballard stated, "The first true s-f story, and one I intend to write myself if no one else will, is about a man with amnesia lying on a beach and looking at a rusty bicycle wheel, trying to work out the absolute essence of the relationship between them". 7 "The terminal beach" comes close to this proposed scenario, and it might be Ballard's most overt piece in this new kind of SF.

“The terminal beach”, also published in New Worlds, is set on Eniwetok or a similar Pacific island that used to serve as testing ground for atomic explosions. A pilot named Traven is voluntarily stranded on the island, trying to come to terms with the premature death of his wife and son. The physical description of the island is almost like a text version of Dali's “The persistence of memory”, suggesting a conflation of past and present time. The island is frequently described by the narrator as a "zone of non-time”, and "a synthesis of the historical and psychic zero", ${ }^{8}$ which provokes in Traven a need to engage in a kind of psychic erasure and ultimately self-annihilation.

The architecture of strange buildings, camera towers, and test platforms is said to be a "continuous concrete cap upon the island, a functional, megalithic architecture as grey and minatory (and apparently as ancient, in its projection into, and from, time future) as any of Assyria or Babylon". ${ }^{9}$ Ballard suggests that this is a kind of future archeological ground, removed from our sense of history and reality to appear alien. Still, it is clear that the shadow of the past of atomic tests has plunged this landscape into a sort of geographical and

\footnotetext{
${ }^{5}$ GASIOREK. J. G. Ballard, p. 9.

6 BALLARD. The best SF of J. G. Ballard, p. 6.

7 BALLARD. A user's guide to the millennium, p. 198.

8 BALLARD. The complete short stories, p. 32.

9 BALLARD. The complete short stories, p. 32.
} 
chronological abjection, transforming it into a site that erases and effectively denies history and humanity.

Traven supplies his own ghosts, those of his dead family, and as he goes deeper into a state of complete deprivation, starving for days, he provokes a sort of fusion between his mind and the environment. "All sense of time soon vanished, and his life became completely existential, an absolute break separating one moment from the next like two quantal events”. ${ }^{10}$ Ballard provides very little in terms of conventional character psychology to describe Traven. Instead, he describes the landscape, the architecture of the buildings, and the strange objects he finds. With "The terminal beach,” Ballard suggests a way of looking at mental processes, conscious and unconscious, by way of geography and spatiality. By doing so, he draws on the Gothic tradition of examining structures that project and introject certain anxieties and desires that can go by unnoticed on everyday life. In a sense, landscapes and buildings can be metaphors for a number of psychological, moral, and aesthetic issues. In Ballard's works, as in Gothic fiction and Surrealism, these external structures are often projections that embody in one way or another unspoken tensions, contradictions, and thought processes of their inhabitants and designers.

In the light of Ballard's manifesto, "Which way to inner space”, we can posit Traven as the "man with amnesia," not so much with a loss of memory but with an unusual sense of memory, one that conflates past, present, and future. The beach is, symbolically, not only a primordial setting, but one that explicitly alludes to the cyclic nature of time, in constant renewal, erasure and erosion. The bicycle wheel is an allusion to a piece by artist Eduardo Paolozzi of the Independent Group's exhibition of contemporary art “This is tomorrow” in 1956, one that the theorist Scott Bukatman says could be the inspiration for many of Ballard's texts, especially Crash, High-rise, and The atrocity exhibition. ${ }^{11}$ Here is an excerpt from Ballard's autobiography, Miracles of life (2007) about the event:

\begin{abstract}
Another of the teams brought together the sculptor Eduardo Paolozzi, and the architects Peter and Alison Smithson, who constructed a basic unit of human habitation in what would be left of the world after nuclear war. Their terminal hut, as I thought of it, stood on a patch of sand, on which were laid out the basic implements that modern man would need to survive: a power tool, a bicycle wheel and a pistol. ${ }^{12}$
\end{abstract}

10 BALLARD. The complete short stories, p. 35.

11 BUKATMAN. Terminal identity: the virtual subject in post-modern science fiction, p. 43.

12 BALLARD. Miracles of life, p. 188. 
Indeed one can see Traven struggling to find the relationship between the fabricated, physical elements of the present, and the more essential, almost eternal, elements of nature. His mind seeks solace in the synthesis between the two, and in a way, this is the locus of much of Ballard's concerns in his fiction. Gasiorek summarizes Ballard's attempt to "overcome divisions between self and world, the rational and the irrational, the conscious and the unconscious - sublating them in a liberatory synthesis”. ${ }^{13}$ Ballard's fiction is often located within this border zone, searching for a synthesis of opposite elements that should lead to liberation.

Gasiorek sees Ballard's appropriation of Surrealism as a technique. SF, on the other hand, provides a rich vocabulary that Ballard finds attuned to the time and that he has claimed as the true literature of the twentieth century. But his fiction is remarkably uninterested in the commonplace, and while he does adopt at that point SF as his nominal genre, his concern is elsewhere. The trope of sublating time and space with internal psychology is not unique to Surrealism either - it approximates Ballard to the Gothic. David Punter, in The literature of terror, warns that the Gothic is not a unified and consistent movement, but rather a number of novels that were later grouped under the same moniker. These were written by authors such as Horace Walpole, Ann Radcliffe, Matthew Lewis, C. R. Maturin, and Mary Shelley; they featured haunted houses and castles, extreme sensation and situations of terror. ${ }^{14}$

At first sight, there is very little to connect Ballard to the nominal Gothic fiction of that period, but Punter lists other, more punctual and pervasive features of the Gothic, such as the restricted access to an "objective” world, being instead narratives immersed in the psyche of the protagonist, but more importantly, its development into a literature of "landscapes of the mind, settings which are distorted by the pressure of the principal characters' psychological obsession". ${ }^{15}$ The use of physical settings to illustrate, influence, and contain the workings and the states of the mind is a thoroughly Gothic trope, as is the concern with psychic and social decay, a "tone of desensitized acquiescence in the horror of obsessions and prevalent insanity". ${ }^{16}$ With the latter, Punter might as well be describing Ballard's The atrocity exhibition, which is, in general terms, about the death of affect and about giving voice to a looming sense of insanity.

\footnotetext{
13 GASIOREK. J. G. Ballard, p. 9.

14 PUNTER. The literature of terror, p. 8.

15 PUNTER. The literature of terror, p. 12.

16 PUNTER. The literature of terror, p. 13.
} 
“The terminal beach" even figures a couple of overt conventions of the Gothic, such as the obsession with architectural ruins and decay, and the haunting visions of Traven's dead wife and son, both elements that tie him to the past. In this short excerpt, "The terminal beach” reads like something out of Edgar Allan Poe:

His wife's pale features seemed illuminated from within, her lips parted as if in greeting, one hand raised to take his own. His son's face, with its curiously fixed expression, regarded him with the same enigmatic smile of the child in the photograph. "Judith! David!" Startled, Traven ran forwards to them. Then, in a sudden movement of light, their clothes turned into shrouds, and he saw the wounds that disfigured their necks and chests. Appalled, he cried out. ${ }^{17}$

This is a typical Gothic situation: ghosts luring the living and eventually provoking fear and terror. Their appeal lies in their apparent ability to cheat death, but in uncanny fashion, the appearance is revealed false by exposing their wounds and shrouds. This makes explicit Ballard's debt to the genre, but he updates many of its conventions and concerns through other, subtler ways. One is the use of the uncanny in relation to spaces, real and imagined.

In "The terminal beach", there is a striking space consisting of two thousand concrete blocks, perfect cubes of 15 cubic feet, spaced at 10 yards. One of the sides of these cubes holds a door, visible only at a certain angle (not unlike the surrealistic trompe l'œil), and the blocks are described as having the "size and air of a house". ${ }^{18}$ Inside them, Traven finds solace and the fatigue that took over his body vanishes. "For the first time since his arrival at the island, the sense of dissociation set off by its derelict landscapes began to recede". ${ }^{19}$ If the alien, inhospitable landscape of the island is uneasy to Traven, the homelike "concrete monsters” give him comfort.

Here Freud's essay “The uncanny” (1919) can be of help. Freud suggests, by etymologically analyzing the word "unheimlich" (uncanny), that which is (literally) "homely" or "heimlich" ends up having also its opposite meaning, that is, "unheimlich” (unhomely). Following Ernst Jentsch's definition of Unheimlich as that which “ought to have remained secret and hidden but has come to light", ${ }^{20}$ Freud develops the uncanny as a manifestation of the unconscious process of repression. What is uncanny is at the same time unfamiliar and strange but is also homely and familiar, thus articulating hidden and repressed tensions by

\footnotetext{
17 BALLARD. The complete short stories, p. 45.

18 BALLARD. The complete short stories, p. 46.

19 BALLARD. The complete short stories, p. 38.

20 FREUD. The uncanny, p. 34.
} 
bringing them to light, and is a mark of the return of the repressed. Much of the Gothic, and for that matter, of all that provokes terror, is triggered by uncanny elements that force us to come to terms with taboos or uncomfortable, forgotten ideas. It is still homely because it is instantly recognizable, and pertains to primitive and infantile feelings that morality, ethics, and values consistently efface and repress. Quoting Freud, “[T]he uncanny is uncanny only because it is secretly all too familiar, which is why it is repressed". ${ }^{21}$ For now, it suffices to understand how the blocks in "The terminal beach" have for Traven an uncanny role, one that allows the elision of past and present, conscious and unconscious, inner and outer space. These interstitial spaces are numerous in Ballard's fiction, and it may even be said that much of his work fulfills the same role on a genre, or category, level. Stories such as "The terminal beach" use this blurred interstitial zone to comment on the unspoken role of spaces in the postwar world, working by way of Gothic, SF, and surrealist conventions to explore the hidden logics of a largely chaotic and irrational world.

“The terminal beach" seems to be the ideal starting point for an inquiry because it is one of Ballard's early attempts to put all those elements together, while explicitly locating his text in history. The island is a former H-bomb test site. Consequently, being that the landscape becomes a fusion of Traven's psyche and the actual, physical world, it is possible to extrapolate Traven's obsessions and fears onto a larger sphere: his fragmented consciousness and fixation with past events, both his family's death and the history of the landscape, that of the atomic bomb. The story was written at the height of the Cold War, but there is a sense that the bomb caused a profound change in Western civilization. In a later text, his semi-autobiographical novel Empire of the sun, Ballard elects the Nagasaki bomb as the turning point not only of World War 2 and his fictional stand-in's place in it (at the time a prisoner of war in China) but also of his emotional and intellectual maturity, signaling a permanent shift in his imagination.

Dominika Oramus, in her book-length study Grave new world, identifies the gradual internal degeneration of Western civilization in the second half of the twentieth century as a major current in Ballard's fiction. Contemporary reality in later Ballard texts is presented as "post-apocalyptic: though we are not literally living amidst the ruins, the golden age is far behind us and we are witnessing the twilight of the West". ${ }^{22}$ She suggests that this turning point is the bomb, its invention and use, because it makes the human propensity for self-

\footnotetext{
21 FREUD. The uncanny, p. 36.

22 ORAMUS. Grave new world, p. 14.
} 
destruction finally explicit, because it makes total annihilation possible. In a way Ballard's fiction, despite the elements of estrangement widely employed, is about the contemporary world, living in the shadow of irreconcilable and illogical events in history. His texts expose modern man's difficulty in contextualizing the world around him and a consequent crisis of identity.

Self-destruction and catastrophe are manifestations of another Gothic topic, that of death. If we assume the first SF novel to be Mary Shelley's Frankenstein (1818), as Brian Aldiss proposes in his Billion year spree: the true history of science fiction, it also means that the genre sprung out of the Gothic. The technological element in the story is the ability to create a human being by artificial means, out of dead bodies. Victor Frankenstein transgresses many boundaries by making his creature, one of which is the finality of death, a thought that provokes terror and uneasiness. Death itself is put into question, as man can now manipulate this natural fact. That haunting preoccupation with death and its relation to technology is at the core of SF, and in early Ballard post-apocalyptic stories such as "The terminal beach".

In later Ballard texts, subjectivity toward all elements of life, including death, is increasingly more pervasive and progresses at an enormous rate, as in Crash (1973), in which death is seen as the logical next step of an extremely abstract approach to sexuality and technology. Both Concrete island (1974) and The unlimited dream company (1979) seem to be creative explorations of near or actual death experiences, attempts to represent death in fiction and its liberating effect on the imagination. Empire of the sun (1984) contains one of his most complete and provoking approaches to the theme, as the delirious protagonist, Jim, sees a reversal of the process of death and experiences the dead coming back to life towards the end of the novel - the looming presence of the Nagasaki bomb determining the outcome of Jim's predicament and the war. That scene from Empire of the sun is almost a recreation of a portion of "The terminal beach", in which Traven finds the body of a Japanese man in a crevice. He is not military or science personnel, and, like Traven, has no apparent motive to be on the island, suggesting that he might be in fact Traven's double, a projection of his own self. Hallucinating, he converses with this man, Yasuda, who urges him to exercise a "philosophy of acceptance”, letting go of his guilt and his ties to the past. Ironically, Yasuda can only "accept" this because he is already dead, and has fully merged (body and mind) with the island. As the story ends, Traven drags Yasuda's body, now referred to as "the dead archangel”, from the crevice and uses it as a "guardian”, to keep Traven away from the blocks (which seem to accelerate his process of dissolution). In a sense, he has found a way to 
project his own death onto a double, deflecting his own process of decay, but which remains nonetheless a physical sign of the future.

Freud identified the death drive in Beyond the pleasure principle (1920), describing it as a force that makes living creatures strive for an inorganic state, which is the deeper, primordial, and essential state of things. This concept can be useful to understand how, especially in the kind of fiction we are dealing with, there is an overwhelming concern with death and destruction. It links death with birth and the compulsion to repeat. The energy of the death drive is, according to André Green, a "work of the negative”, and seems always to be related with dissociation, regression, and dissolution. ${ }^{23}$ It is only curious that the sounds of the deathly island, where Traven goes to die and come to terms with the inevitability of death, remind him of the beach at Dover, where he was born, signaling the relation between death and birth, the end and the beginning of life. "The landscape seems to be involved with certain unconscious notions of time, and in particular with those that may be a repressed premonition of our own deaths”, ${ }^{24}$ which constitutes a privileged space in which time is but an illusion. “The terminal beach" tries to convey a psychic reinvention of space, a physical incarnation of all these drives and obsessions, history and psychology together encoded in architecture and spatiality. In a section of the short story titled "The catechism of goodbye", Traven begins a pretense of saying "goodbye" to a location that had been used test sites for atom bombs, such as Eniwetok and Los Alamos. When he does that, one of the blocks disappears: "the corridors remained intact, but somewhere in his mind appeared a small interval of neutral space”. Eventually he stops, realizing that if he kept on, he would have to "fix his signature upon every one of the particles of the universe". ${ }^{25}$ If we follow Freud's explanation of the death drive as a principle of stability and his affirmation that the dominating tendency of mental life is the "effort to reduce, to keep constant or to remove internal tension due to stimuli", 26 Traven's saying "goodbye” is his attempt to reduce tension, or his guilt, physically present as the blocks. The only way to set the mental tension to zero, and deplete the landscape of the ominous blocks, is death, and is, we assume, Traven's destiny.

Ballard often isolates characters in settings, as he has done in "The terminal beach", in ways that the socio-historical context becomes embedded in the physical landscape, which is

\footnotetext{
23 GREEN. The work of the negative, p. 85.

24 BALLARD. The complete short stories, p. 40.

25 BALLARD. The complete short stories, p. 46.

${ }^{26}$ FREUD. Beyond the pleasure principle, p. 56.
} 
also informed by the psychology of the characters. These closed and almost controlled spaces become perfect stage sets in which he can enact the key problems of urban alienation and the death of affect. This kind of isolation disallows appeals to exterior forces, relying primarily on the external/physical and internal/mental spaces of the characters. A powerful technique, it yields disturbing and cogent results, asserting the ongoing importance of certain surrealist tropes in contemporary art and literature, as well as the force of the compressed form. Both these ideas can be traced back to Freud's description of the dream-work in 1900, the conflation of conscious and unconscious stimuli in one narrative, and the workings of condensation and displacement. Ballard's metaphors and imagery are often dream-like, but the narrative form of dreams seems to have influenced him the most. The synthesis of subject and object, character and setting, internal and external, reality and fiction, are all marked features his style.

The study of spaces in literature began to receive special attention with the Gothic, and is now more important than ever. As Ballard has stated, the difference Freud pointed out between the latent and the manifest content of a dream now has to be applied to reality. ${ }^{27}$ It is as if reality and fiction have traded places, and our experience of reality must be guided by fictional and dream states. To truly comprehend an actual space, we must look at its subtext, at its latent content. Michel Foucault suggested that

a whole history remains to be written of spaces - which would at the same time be the history of powers (both these terms in the plural) - from the great strategies of geo-politics to the little tactics of the habitat, institutional architecture from the classroom to the design of hospitals, passing via economic and political installations. ${ }^{28}$

Foucault notes that spaces are not only physical locations but also embodiments of a subtext of power. Relations of authority and power are encoded in the way hospitals and schools, for instance, are designed, and the act of looking beyond the manifest content of reality provides a powerful tool of analysis. Ballard too ascribes the same importance to spaces, an obsession that takes full form in two of his novels of the 1970s - Concrete island and High-rise - tales of urban alienation and psychological and physical entrapment. Set in contemporary locations of everyday life, but isolated in time and space, they are Ballard's most developed explorations of the theme of space and modern man's dislocation in the world.

27 BALLARD. Re/search 8/9, p. 103.

28 FOUCAULT. Power/knowledge: selected interviews and other writings, 1972-1977, p. 149. 
Gasiorek suggests that the two novels occupy opposite ends of the civic spectrum: "one exposes the hidden byproducts of contemporary life, while the other concentrates on its dreams of rational design". ${ }^{29}$ In Concrete island, an architect crashes his car in a deject traffic island among interceding carriageways, and finds himself unable to escape. The traffic island is inhabited by some of society's rejects and is a byproduct of late twentieth-century urban planning, a forgotten space that may or not be a projection of the dying architect's mind. In High-rise, written shortly thereafter, a thousand-apartment building set on the outskirts of London answers the problems of modernity by compartmentalizing and embodying every living need and comfort possible for its inhabitants, a utopia in the manner of the architect Le Corbusier. It quickly turns into a dystopia, one without a discernible particular cause, as people living in the high-rise find the need to liberate their atavistic impulses, descending into barbarism and full-fledged clan warfare, indulging in every kind of moral transgression, including rape and murder. Ballard's characterization is more concerned with the architecture and the artificial social organization imposed by the spaces themselves than with conventional character psychology. All the action takes place inside such spaces, without hardly any mention of other locations, suggesting that the relation of space and individual is more than just physical. It is as if any of the events of both texts, either actual or psychological, could never take place if not for the influence of the unusual surroundings, which asks for a reading that considers Ballard's treatment of space and architecture, and how it relates to human psychology.

By tracing the influences of the Gothic in Ballard's work - particularly those related to the representation of space and the body - there will be new insights into these complex, unassimilated and almost uncategorizable texts. Roger Luckhurst, in his book The angle between two walls, points out the elusive character of Ballard's texts: "His work at once constantly activates theoretical models, but it is also awkward, didactic, and overtheorized, tending to evade or supersede the theories meant to 'explain' it”. ${ }^{30}$ To be sure, a great number of postmodern theorists and academics "use" Ballard to illustrate and explain many works of art made possible by new technology, such as video art and cyberpunk. Ballard is often invoked to show how SF writers have anticipated a contemporary sensibility; for example, the fusion of man and machine so explored in cyberpunk, is thought to have sprung out of Crash. Jean Baudrillard famously takes the novel and uses it to explain his theory of simulacrum, not

29 GASIOREK. J. G. Ballard, p. 120.

${ }^{30}$ LUCKHURST. The angle between two walls: the fiction of J. G. Ballard, p. xviii. 
the other way around. Still, there are few book-length studies of Ballard's fiction, although he is widely known and seen as a paragon of SF New Wave and cyberpunk and a huge influence in media studies. He is barely read in the United States (his last published novel in the country is 2000's Super-Cannes) and it appears that whereas he is superficially known, his fiction remains unassimilated by readers and theorists.

The ideas expounded in his texts are extremely prescient, both because they have aged better than a great number of his contemporaries' in the SF field, and mainly because they have anticipated psychological and social changes triggered by technology, rather than just the technological changes themselves. For Ballard, "SF is a response to science and technology as perceived by the inhabitants of a consumer goods society", ${ }^{31}$ and in a sense it should accurately portray, project, and anticipate the true paradigm shift, the one inside our heads. As Ballard took that into account, and described an "external reality ontologically transformed by the multiplicity of electronic signals in the air,” or as Bukatman terms it, the "mediascape", 32 he has seen how the imaginary space of mass media began to take hold of reality in the 1960s, something that became evident to theorists in the 80s, with the advent of cyberpunk and cyberspace.

The techniques of surrealism have a particular relevance at this moment [1966], when the fictional elements in the world around us are multiplying to the point where it is almost impossible to distinguish between the "real" and the "false" - the terms no longer have any meaning. ${ }^{33}$

Undoubtedly Ballard employs surrealist techniques because he identifies them taking place in a much larger scale, again stressing his pressing concern with the socio-historical sphere. Oramus stresses that

irrespectively of the literary conventions Ballard applies in a given text (science fiction, speculative fiction, detective story, thriller, war novel or any other), he charts the very same territory and remains throughout primarily interested in the reaction of the human mind to the post-World War II reality which is the common denominator of his diverse obsessions. ${ }^{34}$

Ballard's preoccupation with the present and the technological and social developments since the war is certainly paramount, but we must look into his uses of the

\footnotetext{
${ }^{31}$ BALLARD. Re/search 8/9, p. 99.

32 BUKATMAN. Terminal identity: the virtual subject in post-modern science fiction, p. 42 .

${ }^{33}$ BALLARD. A user's guide to the millennium, p. 88.

${ }^{34}$ ORAMUS. Grave new word, p. 23.
} 
conventions and the genres he employs to understand how general and wide his insights really are. The act of comparing and tracing the development of the uses of certain literary tropes over time is fundamental to contextualize and represent the subject. To better understand Ballard's fiction and his representation of the landscapes of the mind and their meaning as literary creations and social observations, his use of certain techniques and the largely unexplored affinity with the Gothic and its relation to architecture and the representation of space must be investigated.

\section{RESUMO}

A ficção de J. G. Ballard lida com espaços, tanto internos quanto externos. Influenciado pelo Surrealismo e psicanálise freudiana, Ballard explora a linha tênue entre mente e corpo. Esta análise do conto “The terminal beach” ilustra alguns desses conceitos presentes na sua obra como um todo.

\section{PALAVRAS-CHAVE}

Corpo, espaço, o estranho

\section{REFERENCES}

BALLARD, J. G. The best SF of J. G. Ballard. London: Futura, 1977.

BALLARD, J. G. Re/search 8/9. San Francisco: ReSearch Pub, 1984.

BALLARD, J. G. A user's guide to the millennium. New York: Picador, 1996.

BALLARD, J. G. The complete short stories. London: Harper, 2006. v. 2.

BALLARD, J. G. Miracles of life. London: Harper, 2007.

BUKATMAN, Scott. Terminal identity: the virtual subject in post-modern science fiction. Durham: Duke University Press, 1993.

FOUCAULT, Michel. Power/knowledge: selected interviews and other writings, 1972-1977. Brighton: Harvester, 1980.

FREUD, Sigmund. The uncanny. New York: Penguin, 2001.

FREUD, Sigmund. Beyond the pleasure principle. New York: Penguin, 2003.

GASIOREK, Andrzej. J. G. Ballard. Manchester: Manchester University Press, 2005.

GREEN, André. The work of the negative. London: Free Association, 1999.

LUCKHURST, Roger. The angle between two walls: the fiction of J. G. Ballard. Liverpool: Liverpool University Press, 1997. 
ORAMUS, Dominika. Grave new world. Warsaw: Warsaw University Press, 2007.

PUNTER, David. The literature of terror. $2^{\text {nd }}$ ed. Cambridge: Cambridge University Press, 2003. 